\title{
How Unitary is the EU Trade Mark? Territorial Aspects of Acquired Distinctiveness
}

\author{
Lukasz Żelechowski (D)
}

Published online: 6 April 2020

(C) The Author(s) 2020

\begin{abstract}
The geographical scope of the acquired distinctiveness of EU trade marks (EUTMs) is the subject of recurring dilemmas in case law and among scholars. The development of case law in this area is driven by the endeavour to reconcile the requirement that the acquired distinctiveness of such marks ought to be present throughout all Member States while simultaneously allowing certain evidentiary relaxation in that regard. Ultimately, however, the content of the requirements of establishing acquired distinctiveness in such instances remains, in the light of case law, uncertain. This paper argues that the principle of the unitary character of EUTMs should lead to adopting a more unitary approach towards the assessment of acquired distinctiveness, instead of the country-by-country approach dominant in case law. More specifically, whenever no territorially varying consumer perceptions are involved in establishing a lack of inherent distinctiveness of an EUTM, the territory of the EU should be treated, for the sake of establishing acquired distinctiveness, as a monolith undivided by borders between the Member States. This is normally the case with non-word marks, such as shapes or colour marks, which are perceived in a uniform manner throughout the EU as either possessing or lacking inherent distinctiveness. Concessions from this unitary approach are justified whenever territorially varying perceptions are involved. This normally concerns the descriptiveness or otherwise non-distinctiveness of word marks due to linguistic differences that are tailored across borders between Member States. The posited unitary approach concerning non-word marks should, however, be a measured one. Not only should acquired distinctiveness be present in the majority of the EU territory, but it should also be located at a proper geographical spread (without, however, following the country-by-country method). In the light of this approach, a non-word EUTM could still be registered (and remain incontestable) based on acquired distinctiveness when EU territories where acquired distinctiveness has not
\end{abstract}

Ł. Żelechowski (ه)

Dr, Assistant Professor, Faculty of Law and Administration, University of Warsaw, Warsaw, Poland e-mail: 1.zelechowski@wpia.uw.edu.pl 
been established would constitute "blank" areas sporadically scattered across the Union without, however, constituting a concentrated larger part of the EU. Such "blank" areas could correspond to territories of a specific Member State or Member States. Negative effects of overprotection in such "blank" areas could be subsequently prevented with additional mitigating tools available at the stage of infringement and enforcement of EUTMs.

Keywords Acquired distinctiveness - Distinctiveness · European Union trade mark · Territoriality · Unitary character · Trade mark registration

\section{Introduction}

The registration of a European Union Trade Mark (EUTM) by the European Union Intellectual Property Office (EUIPO) leads to the grant of a right to the EUTM that is effective throughout the entire territory of the EU. It is not merely a bundle of national rights in Member States. One of the cornerstones of the EUTM system is the principle of the unitary character of the EUTM. It is expressed in Art. 1(2) of Regulation 2017/1001 on the European Union Trade Mark (EUTMR) ${ }^{1}$ which stipulates as follows:

An EU trade mark shall have a unitary character. It shall have equal effect throughout the Union: it shall not be registered, transferred or surrendered or be the subject of a decision revoking the rights of the proprietor or declaring it invalid, nor shall its use be prohibited, save in respect of the whole Union. This principle shall apply unless otherwise provided for in this Regulation.

The answer to the question "How unitary is the EUTM?" or - in other words - how deeply does the principle of unitary character permeate the system of protection of EUTMs is, however, not so obvious. Indeed, the enormous territorial scope of the exclusive right to the EU trade mark, which has been extended several times in connection with the accession of new Member States, is a source of very specific problems connected with the principle of unitary character. These have become highly debated in recent years. It is possible to distinguish at least four such issues: ${ }^{2}$ (1) assessment of acquired distinctiveness of the EUTM in the context of registration or invalidation proceedings, which is the subject of a closer examination in this paper; (2) genuine use of the EUTM in the EU; ${ }^{3}$ (3) geographical scope of prohibitive injunctions in the case of infringements of EUTMs; ${ }^{4}$ and (4)

\footnotetext{
${ }^{1}$ Regulation (EU) 2017/1001 of 14 June 2017 on the European Union trade mark, OJ L 154, 16 June 2017, pp. 1-99; this replaced Regulation (EC) No. 207/2009 of 26 February 2009 on the Community trade mark, OJ L 78, 24 March 2009, pp. 1-42, which replaced the earlier Regulation (EC) No. 40/94 of 20 December 1993 on the Community trade mark, OJ L 011, 14 January 1994, pp. 1-36.

2 Dinwoodie (2017), p. 1693.

3 CJEU, 19 December 2012, Case C-149/11, Leno Merken/Hagelkruis Beheer.

4 CJEU, 12 April 2011, Case C-235/09, DHL/Chronopost; 22 September 2016, Case C-223/15, combit Software/Commit Business Solutions.
} 
geographical scope of reputation of the EUTM in the EU for the sake of granting the so-called extended protection of a trade mark enjoying a reputation. ${ }^{5}$

The territorial aspect of establishing acquired distinctiveness of an EUTM is a particularly complex problem when a given mark lacks inherent distinctiveness in the entire EU. The question then arises as to whether acquired distinctiveness must be demonstrated for the territory of each Member State, or should the territory of the internal market of the EU (being the territory in which the unitary EUTM is effective) be merged into a single unit undivided by borders between Member States. Discussion in this regard has been propelled in recent years by developments in case law, notably by the judgment of the Court of Justice in the Mondelez ${ }^{6}$ case. This paper seeks to analyse the extent to which arguments derived from the principle of unitary character should shape the approach towards the assessment of acquired distinctiveness of EUTMs.

This introduction is followed by a concise outline of the legal framework of establishing acquired distinctiveness of EUTMs in Sect. 2. Next, Sect. 3 examines reasons for the territorially varying perceptions of consumers in the EU and their impact on the assessment of a lack of distinctiveness as a refusal ground in registration proceedings. Section 4 contains an analysis of the case law concerning the territorial aspect of acquired distinctiveness of EUTMs with regard to the perplexing problem of non-word EUTMs perceived as inherently indistinctive in the entire EU. The analysis is conducted with a view to identifying factors which drive the development of case law in this area. Section 5 is divided into three sub-sections that seek to determine how the unitary character of the EUTM should shape the approach towards the territorial aspect of establishing acquired distinctiveness of EUTMs at the stage of registration. Section 6, in turn, explores mechanisms available at the level of assessing the requirements of an infringement action that could be employed to mitigate the excessive effects of unitary protection of EUTMs registered with acquired distinctiveness. Section 7 concludes the paper.

\section{Legal Framework}

Pursuant to Art. 7(1)(b)-(d) EUTMR, registration is excluded in the case of trade marks which are: (1) devoid of any distinctive character (Art. 7(1)(b) EUTMR); (2) consist exclusively of signs or indications which may serve, in trade, to designate the kind, quality, quantity, intended purpose, value, geographical origin or the time of production of the goods or of rendering of the service, or other characteristics of the goods or services (Art. 7(1)(c) EUTMR); or (3) consist exclusively of signs or indications which have become customary in the current language or in the bona fide and established practices of the trade (Art. 7(1)(d) EUTMR). Furthermore, an EUTM registered contrary to any of the absolute grounds for refusal (examined by the EUIPO ex officio in registration proceedings) set out in Art. 7(1) EUTMR,

\footnotetext{
5 CJEU, 6 October 2009, Case C-301/07, PAGO/Tirolmilch; 3 September 2015, Case C-125/14, Iron \& Smith/Unilever; 20 July 2017, Case C-93/16, Ornua/Tindale \& Stanton.

${ }^{6}$ CJEU, 25 July 2018, Joined Cases C-84/17 P, C-85/17 P and C-95/17 P, Nestlé/Mondelez/EUIPO.
} 
including subsections (b), (c) and (d), can be declared invalid pursuant to Art. 59(1)(a) EUTMR. A further important rule is set out in Art. 7(2) EUTMR which provides that absolute grounds for refusal laid out in Art. 7(1) EUTMR shall apply notwithstanding that they exist only in a part of the EU. In the light of case law, a part of the EU within the meaning of this provision could be comprised of a territory of a single Member State. ${ }^{7}$

The issue of acquired distinctiveness is directly addressed in Art. 7(3) EUTMR. This provision stipulates that the refusal grounds set out in Art. 7(1)(b), (c) and (d) shall not apply if the trade mark has become distinctive in relation to the goods or services for which registration is requested as a consequence of the use which has been made of it. The distinctive character must essentially be acquired prior to the date of filing for registration. ${ }^{8}$ Article 59(2) EUTMR allows, however, taking into account, in invalidation proceedings, the distinctive character which has been acquired after the registration. While there may be uncertainties as to whether the refusal grounds set out in Art. 7(1)(b)-(d) EUTMR are all covered by a broad notion of distinctiveness, or whether they rather constitute overlapping, but separate categories located at the same level of classification, ${ }^{9}$ it is clear that acquired distinctiveness under Art. 7(3) EUTMR allows any of these three refusal grounds to be overcome and in that sense it has an overreaching meaning.

A set of rules regarding the assessment of acquired distinctiveness has been developed in case law in the light of harmonised EU trade mark law, contained currently in Trade Mark Directive 2015/2436 (TMD) ${ }^{10}$ and in the EUTMR. Among factors which ought to be taken into account in this case one should distinguish, in particular, the market share held by the mark; the intensity, geographical spread and duration of the use of the mark; the amount invested by the trader in promoting the mark; the proportion of the relevant class of persons who, because of the mark, identify goods as originating from a particular undertaking; and statements from chambers of commerce and industry or other trade and professional associations. ${ }^{11}$ Establishing acquired distinctiveness requires a global assessment of evidence presented by the trade mark applicant. ${ }^{12}$ The acquisition of a distinctive character by a trade mark following its use requires that at least a significant part of the relevant public identifies the goods or services covered by the trade mark application as

\footnotetext{
${ }^{7}$ E.g. CJEU, 22 June 2006, Case C-25/05 P, August Storck/OHIM, para. 83.

${ }^{8}$ CJEU (General Court), 24 February 2016, Case T-411/14, The Coca-Cola Company/OHIM, para. 67.

${ }^{9}$ Cf. Kur, in: Kur and Senftleben (2017), pp. 110-116.

${ }^{10}$ Directive (EU) 2015/2436 of 16 December 2015 to approximate the laws of the Member States relating to trade marks, OJ L 336, 23 December 2015, pp. 1-26. This replaced the earlier Directive 2008/95/EC of 22 October 2008 to approximate the laws of the Member States relating to trade marks, OJ L 299, 8 November 2008, pp. 25-33, which replaced Directive 89/104/EEC of 21 December 1988 to approximate the laws of the Member States relating to trade marks, OJ L 40, 11 February 1989, pp. 1-7. ${ }^{11}$ CJEU, 4 May 1999, Joined Cases C-108/97 and C-109/97, Windsurfing Chiemsee/Boots-und Segelzubehör Walter Huber and Franz Attenberger, para. 51; with regard to EUTMs, see e.g. CJEU, 22 June 2006, Case C-25/05 P, August Storck/OHIM, para. 75.

12 CJEU, 4 May 1999, Joined Cases C-108/97 and C-109/97, Windsurfing Chiemsee/Boots- und Segelzubehör Walter Huber and Franz Attenberger, para. 49.
} 
originating from a particular undertaking. ${ }^{13}$ The assessment must take into account the presumed perception of that mark by an average consumer of the category of goods or services concerned, who is reasonably well-informed, reasonably observant and circumspect. ${ }^{14}$ Market surveys may be used to establish the above circumstances. The case law clearly highlights, however, the inability to provide any general and abstract data necessary in this respect, such as predetermined percentages. $^{15}$

In light of the above, establishing acquired distinctiveness is based on a global assessment of a multiplicity of factors with no unique or dominant role attributed to the issue of the territorial scope of acquired distinctiveness. This is a viable approach in the case of national marks ${ }^{16}$ and the unitary character of EUTMs might encourage approaching this issue no differently. The geographical area of the EU combined with questions concerning the level of integration of the internal market render, however, the sole territorial aspect of acquired distinctiveness of the EUTM the subject of constantly recurring dilemmas in case law and legal doctrine, as demonstrated further in this paper. This might already of itself be evidence that this issue is characterised by some uniqueness that cannot be disregarded.

\section{Territorially Varying Perceptions of Consumers in the EU}

A situation in which consumer perceptions concerning distinctiveness of an EUTM, evaluated from the perspective of the model of the average consumer, could be considered as always being the same across the EU would be ideal. Such an ideal situation is not, however, a reality. Integration of the internal market, although advanced, is far from being complete and factors such as borders between Member States and linguistic or cultural differences may contribute to varying consumer perceptions. ${ }^{17}$ This section of the paper examines the extent to which varying consumer perceptions are relevant for assessing the inherent distinctiveness of EUTMs, in order to provide a background for subsequent considerations concerning acquired distinctiveness.

In a series of judgments, the case law to date has drawn a line between cases of non-word marks and word marks. The assessment of inherent distinctiveness of non-word marks will, in principle, give a universal result in the sense that a given

\footnotetext{
13 CJEU, Case C-299/99, Koninklijke Philips Electronics/Remington Consumer Products, para. 64.

14 CJEU, Case C-299/99, Koninklijke Philips Electronics/Remington Consumer Products, para. 63; 22 June 2006, Case C-25/05 P, August Storck/OHIM, para. 25.

15 CJEU, 4 May 1999, Joined Cases C-108/97 and C-109/97, Windsurfing Chiemsee/Boots- und Segelzubehör Walter Huber and Franz Attenberger, paras. 52-53.

${ }^{16}$ In the light of the TMD, the issue of the territorial scope of acquired distinctiveness came up in the judgment of the CJEU, 7 September 2006, Case C-108/05, Bovemij Verzekeringen/Benelux-Merkenbureau, paras. 22-23, in which the CJEU ruled that acquired distinctive character must be present throughout the part of the territory of the Member State or, in the case of Benelux, throughout the part of the territory of Benelux in which a ground for refusal existed.

17 Cf. Study (2011), pp. 61-64 (paras. 1.66-1.78); Kur (2012), pp. 754 and 760; Dinwoodie (2017), p. 1693.
} 
mark will be perceived as either possessing or not possessing distinctiveness throughout the entire EU without a territorial diversification, unless there is concrete evidence against such an evaluation in specific circumstances. ${ }^{18}$ This approach is based on the assumption that perceptions of relevant circles of consumers or other final purchasers of goods or services concerning distinctiveness will usually not differ in individual parts of the EU with regard to non-word marks. These are understood in this paper to be marks without any word elements, such as purely figurative marks, shapes and colour marks, ${ }^{19}$ as well as letters or numerals that are merely typographical expressions. ${ }^{20}$ Indeed, a lack of inherent distinctiveness of a non-word mark has normally been established in judicial decisions for the entire territory of the EU without any specific reference to a given part of the EU. ${ }^{21}$

This paper does not examine a more general issue of whether the average consumer in EU trade mark law is a fictitious, purely legal construct or whether it might require empirical grounding. ${ }^{22}$ Neither does it seek to resolve whether such average consumer is a model with uniform reactions across the EU, or rather a collection of national consumers. ${ }^{23}$ It is, however, relevant for further considerations to stress that the above-mentioned approach towards the assessment of inherent distinctiveness of non-word marks demonstrates that this is an instance in which the uniformity of assessments made with regard to the territory of the internal market as a single undivided territory of protection of the EUTM is not just a pure theory, but an existing phenomenon.

The situation is, indeed, different in relation to word marks. In this case, a mark is often descriptive under Art. 7(1)(c) EUTMR, generic under Art. 7(1)(d) EUTMR or otherwise indistinctive under Art. 7(1)(b) EUTMR. This is due to linguistic factors existing in specific parts of the EU. Various scenarios are, however, possible. First, if a trade mark is descriptive (or generic) or otherwise indistinctive in any of the official languages of the EU, this constitutes a bar to registration in a part of the EU (Art. 7(2) EUTMR). Consequently, the mark is precluded from registration as an

\footnotetext{
18 CJEU (General Court), 29 November 2004, Case T-399/02, Eurocermex SA v. OHIM, para. 47; 10 November 2004, Case T-402/02, August Storck/OHIM, para. 86; 12 September 2007, Case T-141/06, Glaverbel/OHIM, para. 36; 21 April 2015, Case T-359/12, Louis Vuitton Malletier/OHIM, para. 87; 6 November 2014, Case T-53/13, Vans/OHIM, para. 96; 24 February 2016, Case T-411/14, The Coca-Cola Company/OHIM, para. 68.

19 Knaak (2001), p. 669.

${ }^{20}$ Kur, in: Kur and Senftleben (2017), p. 203; this could also apply to abbreviations. In this case, however, arguing uniform perceptions thereof in the EU might require a more concrete justification; $c f$. fn. 30 .

21 E.g. stressed by the CJEU (General Court), 15 December 2005, Case T-262/04, BIC/OHIM, para. 68. A uniform presence of an EU-wide lack of inherent distinctiveness was also noted in the decision of the Second Board of Appeal, 11 December 2012, Case R0513/2011-2, Nestlé/Cadbury (later Mondelez), para. 73.

22 On these issues in particular, Davis (2005), p. 183; Davis (2015), p. 15; Dinwoodie and Gangjee (2018), p. 339.

23 Cf. Dinwoodie and Gangjee (2018), pp. 375-378; Dinwoodie (2017), p. 1714. While the CJEU in the judgment of 22 September 2016, Case C-223/15, combit Software/Commit Business Solutions, accepted a territorially confined infringement of the EUTM due to descriptiveness of a mark in some parts of the EU, it did not address the issue of the (non)existence of the average EU consumer in a straightforward manner, despite a direct question in that regard formulated by the referring court ( $c f$. para. 22).
} 
EUTM. ${ }^{24}$ In such cases, the areas (sub-markets) in relation to which the grounds for non-registrability exist are tailored along the borders between Member States, because official languages of the European Union are used within one country or a group of countries.

Second, varying consumer perceptions caused by linguistic considerations also play a role in establishing the cross-border descriptiveness or otherwise indistinctiveness of a word mark formulated in an official language of the EU used in one Member State or in several Member States. This concerns, in particular, word marks in English which, in a given case, might also be descriptive or otherwise indistinctive in territories of Member States where English is not the native language. In this situation, considering a foreign word or expression to be ineligible for registration does not appear to be a result of a uniform process embracing the internal market as a whole. It rather appears to be predominantly conditioned by individual circumstances in submarkets tailored across linguistic criteria, taking into account the level of knowledge of a foreign language in a given sub-market, the complexity of the word mark, as well as the character of products or services concerned. In this vein, the CJEU's judgment in the Matratzen case ruled that a term in a language of one Member State can be considered as devoid of distinctive character or descriptive in another Member State only when consumers in the latter Member State are capable of identifying the meaning of the term. ${ }^{25}$ For example, the General Court has considered it a well-known fact that a basic understanding of English by the general public is present in the Scandinavian countries, the Netherlands and Finland, ${ }^{26}$ as well as in Malta (where English is one of the official languages) and Cyprus. ${ }^{27}$ This position reflects the fragmentation of the internal market which occurs when making findings concerning understanding of a foreign word mark in individual sub-markets. ${ }^{28}$ This might be true even if the mark is eventually found to be descriptive everywhere in the EU. Furthermore, establishing in which EU Member States a word mark is descriptive or otherwise indistinctive might not be an easy task and the same case might be subject to a different assessment by subsequent adjudicating bodies. ${ }^{29}$ Similar conclusions might apply to abbreviations derived from foreign words, in particular English words, although in such cases a more uniform approach to establishing descriptiveness or otherwise a lack of distinctiveness in the EU seen as a single territory undivided into linguistic sub-markets cannot be ruled out, especially with regard to technical terms. ${ }^{30}$

\footnotetext{
${ }^{24}$ Knaak (2001), p. 669; Kur, in: Kur and Senftleben (2017), p. 118.

25 CJEU, 9 March 2006, Case C-421/04, Matratzen Concord/Hukla Germany.

26 CJEU (General Court), 26 November 2008, Case T-435/07, New Look/OHIM, para. 23.

27 CJEU (General Court), 9 December 2010, Case T-307/09, Liz Earle Beauty/OHIM, para. 26.

${ }^{28}$ Cf. Bently et al. (2018), p. 979, pointing out in this case the division of the internal market caused by linguistic reasons.

29 Cf. CJEU, 2 December 2009, Case C-553/08 P, Powerserv Personalservice/OHIM, which illustrates a variation of views presented in subsequent decisions of the EUIPO, the BoA, the General Court and the Court of Justice concerning the territorial scope of descriptiveness and - consequently - the territorial aspect of establishing acquired distinctiveness of the word mark "manpower".

${ }^{30} \mathrm{Cf}$. a more unitary approach to assessing descriptiveness that was taken by the CJEU (General Court) in judgments of 3 December 2003, Case T-16/02, Audi/OHIM, paras. 38-39; and 6 July 2011, Case T-318/09, Audi/OHIM, para. 19 (both concerning the mark "TDI" which is the abbreviation of the
} 
It can be added that, in the course of the EU trade mark law reform, the Commission originally proposed to extend the scope of application of absolute grounds for refusal in the TMD regarding national marks in situations when these grounds obtained in Member States other than those where the application for registration was filed. ${ }^{31}$ This proposal would reflect an attempt to overcome the fragmentation of the internal market in national harmonised trade mark laws due to linguistic considerations, among others. However, it was not included in the final text of the TMD.

Third, descriptiveness might be established when a word mark formulated in a language that is not an official language of the EU is, nevertheless, understood by a significant section of the relevant public in at least a part of the EU. Making such an assessment renders it again necessary to refer to varying consumer perceptions. It should also be noted that, in the course of the EU trade mark law reform, the Commission originally proposed to extend the scope of application of absolute grounds for refusal in both the TMD and the EUTMR to situations when these grounds obtained only where a trade mark in a foreign language or script was translated or transcribed in any script or official language of a Member State. ${ }^{32}$ However, this proposal was also not included in the final text of the TMD and the EUTMR.

Summing up, the picture that appears from the above remarks leads to the conclusion that, with regard to assessing inherent distinctiveness or descriptiveness, the relevant criterion for separating cases where a need arises to refer to borders between Member States from cases where such need does not arise is territorially varying consumer perceptions. The latter scenario concerns - as a rule - non-word marks, as already indicated above. It is, however, not inconceivable that exceptionally an assessment of inherent distinctiveness of a non-word mark could be territorially diversified within the EU depending on specific local circumstances or habits of purchasers of goods or services. ${ }^{33}$ In that regard, the case law has constantly stressed that non-word marks can be considered as perceived in the same way throughout the EU, unless there is concrete evidence to the contrary. ${ }^{34}$ By contrast, in cases concerning descriptiveness or otherwise indistinctiveness of word marks it is indeed necessary - as a rule - to refer to sub-markets determined along linguistic criteria, which normally coincide with borders between Member States or groups thereof. This approach is not, however, justified by some universal methodology that would always

\section{Footnote 30 continued}

English term "turbo diesel injection" or "turbo direct injection"); and in the judgment of 5 March 2003, Case T-237/01, Alcon/OHIM, paras. 42-43 (concerning the acronym BSS as a generic term for a "balanced salt solution").

31 Proposal for a Directive to approximate the laws of the Member States relating to trade marks, document $\operatorname{COM}(2013) 162$ final - 2013/0089 (COD), proposed Art. 4(2)(a).

32 Proposal for a Directive, $c f$. fn. 31, proposed Art. 4(2)(b); Proposal for a Regulation amending Council Regulation (EC) No. 207/2009 on the Community trade mark, document COM(2013) 161 final 2013/0088 (COD), proposed Art. 7(2)(b).

33 Such circumstances are, however, difficult to argue, as demonstrated, for example, by the unsuccessful attempt made in Lindt by the applicant who contended that a chocolate bunny lacked inherent distinctiveness only in Germany, since in other Member States chocolate bunnies sold at Easter were unknown, $c f$. CJEU (General Court), 17 December 2010, Case T-336/08, Chocoladefabriken Lindt \& Sprüngli/OHIM, paras. 67-68.

34 Cf. fn. 18. 
require dividing the unitary territory of protection of EUTMs into sub-markets for the sake of assessment of the refusal grounds set out in Art. 7(1)(b)-(d) EUTMR, but it is, so to speak, "enforced" by the fact that linguistic factors causing varying consumer perceptions in such cases usually happen to be tailored across national borders.

Section 5 further examines whether territorially varying consumer perceptions, relevant for assessment of refusal grounds under Art. 7(1)(b)-(d) EUTMR in the sense argued above, could also affect the territorial aspect of establishing acquired distinctiveness of an EUTM under Art. 7(3) EUTMR.

\section{Case Law on Acquired Distinctiveness of Non-word EUTMs: Struggle of Two Factors}

Section 4 takes a closer look at case law concerning the most problematic group of situations where inherent distinctiveness of a non-word mark is absent in the entire EU. The development of case law in this area can be perceived as underpinned by the struggle between two competing factors. The first factor strives towards treating the EU as a monolith undivided by borders between Member States, in order to adhere to the greatest extent possible to the principle of the unitary character of the EUTM. In contrast, the second factor aims to ensure that no EUTM is registered that could be indistinctive in even one Member State. Hence, this is a border-oriented factor. Although the case law clearly favours the latter factor, as presented below, the first factor is not entirely without resonance in judicial decisions.

Early case law accepted that acquired distinctiveness must be determined in a substantial part of the territory in which an EUTM is devoid of distinctive character under Art. 7(1)(b), (c) and (d) EUTMR. In the case of inherent distinctiveness of nonword marks lacking in the entire EU, this meant that acquired distinctiveness should be proved if not for the whole EU, then for a substantial part of it. ${ }^{35}$ This would imply a lack of necessity to always establish, in such cases, acquired distinctiveness throughout all Member States. It is difficult, however, to have a coherent picture of the content of the "substantial part" criterion in the light of this early case law (pre-dating the PAGO decision in which the said criterion was examined - cf. Sect. 5.2). On the one hand, this criterion was expressed in a positive manner as a sufficient requirement for establishing acquired distinctiveness. On the other hand, in some cases it was applied in an exclusionary manner, leading to a denial of sufficient acquired distinctiveness in the EU because of its lack in a given "substantial part" consisting of even one Member State. ${ }^{36}$ The latter approach implied that acquired distinctiveness must actually extend to all "substantial parts" of the EU.

An important vehicle for the development of case law favouring the approach that acquired distinctiveness must be established individually for every Member State was provided by the judgment of the Court of Justice in the Storck case. ${ }^{37}$ It

\footnotetext{
35 CJEU (General Court), 15 December 2005, Case T-262/04, BIC/OHIM, paras. 62 and 69 ("shape of lighter").

${ }^{36}$ CJEU (General Court), 30 March 2000, Case T-91/99, Ford/OHIM, para. 28 (concerning a word mark "OPTIONS"), where France was indicated as the substantial part of the EU.

${ }^{37}$ CJEU, 22 June 2006, Case C-25/05 P, August Storck/OHIM.
} 
concerned a trade mark taking the form of a two-dimensional representation of a shape of a candy in a gold-coloured wrapper. The application was filed for goods, "sweets", and the trade mark was considered to lack inherent distinctiveness. The evidence of acquired distinctiveness provided by the applicant, including surveys, did not extend (irrespective of other shortcomings) to the territories of all Member States, which led the General Court to deny acquired distinctiveness of the mark in question throughout the EU. This position was subsequently accepted by the Court of Justice, which ruled that an EUTM could be registered under Art. 7(3) EUTMR

only if evidence is provided that it has acquired, through the use which has been made of it, distinctive character in the part of the Community in which it did not, $a b$ initio, have such character for the purposes of Art. 7(1)(b). The part of the Community referred to in Art. 7(2) may be comprised of a single Member State. ${ }^{38}$

This position relies, therefore, on ascertaining a link between Art. 7(2) and Art. 7(3) EUTMR, which was forcefully stressed by AG Ruiz-Jarabo Colomer in the opinion in the Storck case. ${ }^{39}$ Furthermore, it leads to formulation of the requirement that an EU-wide acquired distinctiveness must, in any event, like pieces of a puzzle, fill up all the "blank" areas determined in accordance with Art. 7(2) EUTMR. Next, in connection with the view that the part of the Union referred to in Art. 7(2) EUTMR may be comprised of a single Member State, this approach marks a direct path to adopting a country-by-country method. It also relies on the assumption that no EUTM should be registered if it would be denied registration as a national mark in any Member State. ${ }^{40}$

In some subsequent case law the Storck rule was applied very strictly by requiring that the evidence of acquired distinctiveness in the EU must be produced with respect to the territory of every single Member State. ${ }^{41}$ This not only covered situations where there was no evidence at all with regard to some Member States. It also concerned situations where evidence presented with regard to the territories of some Member States was insufficient to establish acquired distinctiveness in those Member States and could not be substituted by sufficient evidence covering territories of other Member States. ${ }^{42}$ This approach might, at first glance, temptingly appear to remain in accordance with the principle of unitary character, by ensuring that an EUTM has acquired distinctiveness throughout all Member States. ${ }^{43}$ Conversely, it could be perceived as undermining the unitary character of EUTMs,

\footnotetext{
38 CJEU, 22 June 2006, Case C-25/05 P, August Storck/OHIM, para. 83.

39 Opinion of AG Dámaso Ruiz-Jarabo Colomer of 23 March 2006, Case C-25/05 P, August Storck/ OHIM, paras. 75-79, in which the AG added that applying the "substantial part" criterion to acquired distinctiveness would undermine the sense of filing for unitary protection before the mark has established itself on the market through use, if the requirements were lower for acquired distinctiveness than for inherent distinctiveness (para. 79).

40 Von Kapff (2017), p. 80 (mentioned in an informative manner, not as an argued position).

41 CJEU (General Court), 12 September 2007, Case T-141/06, Glaverbel/OHIM, paras. 38-44; 29 September 2010, Case T-378/07, CNH Global/OHIM, paras. 30 and 49-50.

42 CJEU (General Court), 12 September 2007, Case T-141/06, Glaverbel/OHIM, para. 44.

43 Sosnitza (2013), p. 107.
} 
because it leads to treating the internal market as a territory necessarily divided into sub-markets marked by borders between Member States for the purpose of determining the acquired distinctiveness of an EUTM.

A more relaxed approach was presented in the judgment of the Court of Justice in the Lindt case, which concerned the shape of a chocolate rabbit with a red ribbon. ${ }^{44}$ The Court of Justice sided with the General Court by ruling that evidence of acquired distinctiveness was insufficient to establish acquired distinctiveness of the mark in question in all Member States. ${ }^{45}$ On a more general level, however, the CJEU found that, in the light of the principle of unitary character, the assessment of the EUTM's acquired distinctiveness did not have to be based on separately considered national markets. The Court stated that "it would be unreasonable to require proof of such acquisition for each individual Member State". ${ }^{46}$ It is worth noting that earlier the Max Planck Trade Mark Study had suggested that prima facie acquired distinctiveness could be claimed when the applicant could demonstrate "substantially exclusive use in all relevant parts of the Community" without being required to provide proof relevant for establishing acquired distinctiveness, such as market shares held by the mark or the amount of investment in all these territories. ${ }^{47}$ The position expressed by the Court of Justice in Lindt is in line with this approach and appears to put more emphasis on distinguishing relevant markets within the EU for the sake of assessing acquired distinctiveness instead of dividing the EU based just on the criterion of national borders.

While, in the cited case law, the main analysis and usually negative conclusions regarding the presence of acquired distinctiveness were focused rather on general shortcomings of evidence and not just insufficient geographical reach, the territorial aspect came fully to the fore in the Mondelez judgment ${ }^{48}$ in which the Lindt formula was examined more comprehensively. The case concerned a shape mark in the form of a representation of the four-fingered "KIT KAT" chocolate bar. According to the Second Board of Appeal (BoA), it was justified, for the purpose of assessing acquired distinctiveness of the mark in question, to merge territories of all Member States into one territory undivided by national borders and determine whether a substantial proportion of consumers in such a territory perceived this mark as an indication of the commercial origin of goods. ${ }^{49}$ The results of the evidence, including surveys covering the territory of the majority of the 15 Member States

\footnotetext{
44 CJEU, 24 May 2012, Case C-98/11 P, Chocoladefabriken Lindt \& Sprüngli/OHIM.

45 CJEU, 24 May 2012, Case C-98/11 P, Chocoladefabriken Lindt \& Sprüngli/OHIM, paras. 61 and 63, and also noted (para. 23) the view of the General Court that even if the applicant could demonstrate acquired distinctiveness in three Member States (Germany, Austria and the United Kingdom) that was insufficient for establishing acquired distinctiveness throughout the EU.

46 CJEU, 24 May 2012, Case C-98/11 P, Chocoladefabriken Lindt \& Sprüngli/OHIM, para. 62. Similarly, earlier CJEU (General Court), 28 October 2009, Case T-137/08, BCS/OHIM, paras. 38-39, in which the presence of acquired distinctiveness of a combination of colours was confirmed.

47 Study (2011), p. 147 (para. 3.77); similarly, von Mühlendahl (2008), p. 67, referring to the presence of acquired distinctiveness in "markets" in the EU as sufficient for allowing a registration.

48 CJEU, 25 July 2018, Joined Cases C-84/17 P, C-85/17 P and C-95/17 P, Nestlé/Mondelez/EUIPO.

49 Second Board of Appeal, 11 December 2012, Case R0513/2011-2, Nestlé/Cadbury (later Mondelez), para. 74.
} 
representing $90 \%$ of the population of the EU at the time of the filing (which was made before the 2004 accession of new Member States), indicated that almost 50\% of the population in that territory identified the shape in question as an indicator of the commercial origin of the product. This was sufficient for the BoA to establish that the mark had acquired distinctiveness throughout the EU before the filing date. The General Court took a different view and emphasised that the substantial proportion of the public should be established, not in the EU viewed as a merged territory, but "throughout" the Union, thus implying a country-by-country approach. In casu, the Court considered, differently from the BoA, that the acquired distinctiveness in the EU of the mark in question could not be confirmed, and annulled the decision of the BoA. ${ }^{50}$

Advocate General Wathelet agreed, in his opinion, with the decision of the General Court as far as the outcome of the case was concerned. However, he made some interesting points of a general nature. In the first line he referred to the criterion of regional and national markets in the EU, stressing that economic operators might group together certain national markets when distributing their goods or services, for reasons such as geographical proximity, historical links or a common language, customs or practices. Next, while accepting that it was necessary to prove the acquired distinctiveness of an EUTM in all relevant markets in the EU, he simultaneously allowed extrapolation of conclusions based on available quantitatively sufficient evidence concerning some national markets to other national markets (for which no evidence or quantitatively insufficient evidence had been provided) based on the criterion of comparability of those markets. As an example, the AG deemed it possible that for certain goods or services, and on account of the comparability of the markets in question, the evidence provided for the Spanish market could also be sufficient for the Portuguese market, or the evidence provided for the United Kingdom market could be sufficient for the Irish market. ${ }^{51}$ However, he found that the General Court was not able to examine this aspect, since the applicant did not establish a comparability of markets in the five Member States for which no sufficient evidence of acquired distinctiveness was provided with other national markets for which the applicant had provided sufficient evidence.

The Court of Justice also sided with the General Court as to the outcome of the case. The legal argumentation was, however, different from that put forward by the General Court, and followed - to some extent - the position of AG Wathelet. The CJEU drew a distinction between, first, acquired distinctiveness throughout the EU

\footnotetext{
${ }_{50}$ CJEU (General Court), 15 December 2016, Case T-112/13, Mondelez/EUIPO, para. 177; in particular, in the General Court's view, the evidence gathered in the case made it possible to establish the existence of acquired distinctiveness in Denmark, Germany, Spain, France, Italy, the Netherlands, Austria, Finland, Sweden and the United Kingdom, the total population of which represented $90 \%$ of the European Union population at the date of the application of the mark, which was not enough to establish that it had acquired distinctiveness throughout the EU.

51 Opinion of AG Wathelet of 19 April 2018, Joined Cases C-84/17 P, C-85/17 P and C-95/17 P, Nestlél Mondelez/EUIPO, para. 78. The Advocate General found further (para. 81) that in the circumstances of that particular case a lack of evidence covering the territory of Luxembourg would not be detrimental, if it could be established that Luxembourg was a part of the same market as France, Belgium or Germany and if sufficient evidence had been provided for one of the latter countries.
} 
as a fact that needed to be proved and, second, evidence that was necessary to prove this fact. ${ }^{52}$ The CJEU stated that while it was not necessary to provide evidence in respect of each individual Member State (the evidentiary aspect), this evidence still had to be capable of establishing the presence of acquired distinctiveness throughout the Member States of the EU (the facts that needed to be proved). ${ }^{53}$ In the light of this distinction, one can conclude that the CJEU was not, as far as facts that need to be proved were concerned, abandoning the country-by-country approach. The CJEU was providing, however, in line with the Lindt judgment, a certain mitigating tool by ruling that demonstrating acquired distinctiveness throughout all Member States does not inevitably require evidence covering, individually, the territory of every single Member State. As the CJEU states, it is not "inconceivable" that respective evidence "is relevant with regard to several Member States, or even to the whole of the European Union [emphasis by the author]". 54

In the Mondelez case, the CJEU further indicates two respective scenarios. The first one concerns the existence of a system of distribution of goods or services labelled with the mark filed for registration, which takes the structure of a crossborder market covering several countries. In this situation, the CJEU considered it possible to recognise collective evidence relating to a given cross-border market distinguished in the light of the marketing strategy of economic operators as relevant for demonstrating acquired distinctiveness in all countries covered by this market. ${ }^{55}$ Second, the CJEU found that acquired distinctiveness in a Member State can be established where "due to a geographic, cultural or linguistic proximity between two Member States, the relevant public of the first has a sufficient knowledge of the products and services that are present on the national market of the second". 56 Both of these scenarios appear to resemble - in a more nuanced manner - the criterion of "market comparability" proposed by AG Wathelet in his opinion. The CJEU did not, however, expressly employ this criterion in the judgment. Ultimately, it appears that the distinction drawn in Mondelez between the sphere of facts and the sphere of evidence is not aimed at confirming the registrability (or incontestability in invalidation proceedings) of an EUTM that might be indistinctive in some Member States. Instead, the Court seems to be "merely" allowing prima facie conclusions concerning the presence of acquired distinctiveness in the territories of Member States not covered by sufficient evidence, based on sufficient evidence covering territories of other Member States. The Court of Justice is, therefore, developing the approach taken earlier in the Lindt

\footnotetext{
52 CJEU, 25 July 2018, Joined Cases C-84/17 P, C-85/17 P and C-95/17 P, Nestlé/Mondelez/EUIPO, para. 79.

${ }^{53}$ CJEU, 25 July 2018, Joined Cases C-84/17 P, C-85/17 P and C-95/17 P, Nestlé/Mondelez/EUIPO, para. 83.

${ }^{54}$ CJEU, 25 July 2018, Joined Cases C-84/17 P, C-85/17 P and C-95/17 P, Nestlé/Mondelez/EUIPO, para. 80.

${ }^{55}$ CJEU, 25 July 2018, Joined Cases C-84/17 P, C-85/17 P and C-95/17 P, Nestlé/Mondelez/EUIPO, para. 81.

${ }^{56}$ CJEU, 25 July 2018, Joined Cases C-84/17 P, C-85/17 P and C-95/17 P, Nestlé/Mondelez/EUIPO, para. 82; earlier, in the same vein, CJEU (General Court), 14 December 2017, Case T-304/16, bet365/ EUIPO, para. 26.
} 
judgment and also expressed, as indicated above, in the Max Planck Trade Mark Study. This approach aims to put emphasis on distinguishing relevant markets within the EU when establishing the acquired distinctiveness of an EUTM rather than requiring separate evidence based just on the criterion of national borders.

Shortly after Mondelez the Court of Justice passed the judgment in the BasicNet case concerning the distinctiveness of a graphic representation of three vertical stripes. Relying on Mondelez the CJEU stated clearly that although it was not necessary to adduce the proof of acquired distinctiveness for each Member State taken individually, the evidence adduced must make it possible to demonstrate the presence of acquired distinctiveness in all EU Member States. ${ }^{57}$ In the circumstances of the case, the CJEU could not find any flaw in the conclusion of the General Court that evidence of acquisition of distinctive character in France, Italy, the Netherlands and the UK, representing approximately $40 \%$ of the population of the EU, was insufficient to establish the acquired distinctiveness of the mark in question in the EU. ${ }^{58}$

One can assume, in the light of the CJEU case law, that if positive conclusions drawn at the stage of registration from such prima facie evidence with regard to the territory of a given Member State were considered as incorrect in invalidation proceedings, or - by means of a counterclaim - in proceedings before an EUTM court, this would open up the contestability of the registration. ${ }^{59}$ Consequently, while, on the one hand, as far as facts that need to be proved are concerned, the Court of Justice does not allow consideration of the internal market as a whole undivided by borders between Member States for the purposes of assessment of acquired distinctiveness, ${ }^{60}$ on the other, it simultaneously struggles to mitigate, on the evidentiary level, the effects of this country-by-country approach by introducing tools which in theory should make it easier to establish acquired distinctiveness in all Member States. It is, however, worth emphasising that in Lindt, Mondelez or Basic Net the mere reference to the latter possibility did not allow the existence of acquired distinctiveness in the EU in the circumstances of these cases to be confirmed. This also appears to be the case in recent judgments of the General Court

\footnotetext{
57 CJEU, 6 September 2018, Case C-547/17 P, Basic Net SpA/EUIPO, para. 28.

58 One should add that the $\mathrm{CJ}$ did not find any flaw in the approach of the General Court, which found that evidence in the form of sworn statements concerning the turnover and sales data relating to the territories of Austria, Germany, Belgium, Spain and Hungary needed to be corroborated by further evidence. It also sided with the General Court that there was no justification for extrapolation of conclusions based on available evidence to the territories of Ireland, Luxembourg and Malta (CJEU, 6 September 2018, Case C-547/17 P, Basic Net SpA/EUIPO, paras. 33-35). Furthermore, the CJ stressed that no evidence or even allegations concerning the existence of acquired distinctiveness had been made by the applicant with regard to the territory of the remaining (15) Member States (para. 36).

59 In a similar vein, in the light of the earlier Lindt judgment, Folliard-Monguiral and Rogers (2013), p. 287 (fn. 71); in this vein also, CJEU (General Court), 28 June 2019, Case T-340/18, Gibson Brands, Inc./EUIPO, para. 75, relying on the CJEU's position in Mondelez.

$60 \mathrm{Cf}$. concerns connected with the CJEU's position in Mondelez noted in report by Grabrucker (2017), p. 153 , para. 6 .
} 
in which the general formula expressed in Mondelez was reiterated. ${ }^{61}$ It is also raised in literature that the specific requirements concerning evidence that would not cover every Member State individually, but would suffice to establish acquired distinctiveness in the EU, remain uncertain. ${ }^{62}$ Attention is also drawn to the fact that although the evidentiary requirements have been loosened in the light of the case law, demonstrating a vast territorial scope of acquired distinctiveness still renders gathering respective evidence burdensome and highly expensive. ${ }^{63}$

The above remarks demonstrate that development of case law concerning the territorial aspect of acquired distinctiveness of an EUTM in cases of an EU-wide absence of inherent distinctiveness is indeed driven by two opposing factors identified at the beginning of this section. The first factor is border-oriented. It aims to ensure that an EUTM is protected only when it is distinctive in every Member State. The second factor is manifested by a certain degree of concession towards taking a more unitary view of the EU for the sake of establishing acquired distinctiveness, at least on an evidentiary level. The final outcome clearly gives, however, priority to the first factor. In the context of distinguishing these two factors, one might refer to the conceptions of "intrinsic" and "political" territoriality of trade mark rights proposed by Graeme Dinwoodie, where the intrinsic territoriality extends to the actual geographical reach of goodwill, whereas the political territoriality is connected with policymaking and "political institutions with territorially defined sovereignty". ${ }^{64}$ From this perspective, the first "borderoriented" factor identified above might be seen as underpinned by the need to give priority to the actual market situation (the actual geographical reach of recognition of the sign by consumers as distinctive). By contrast, the second factor might be seen as representing appreciation of the political territoriality of EUTMs, which is manifested in the principle of the unitary character of an EUTM. This pursues goals promoted by the EUTMR, namely incentivising business expansion in an internal market by providing undertakings with the possibility of obtaining trade mark protection throughout the entire EU regardless of frontiers. ${ }^{65}$ The position of case law is based on the apparent inclination to eliminate any dissonance between these two factors by securing that the formal territorial reach of the unitary right and the actual reach of acquired distinctiveness are the same. This remains in contrast to the position expressed with regard to infringement of an EUTM where the CJEU has already paved the way towards finding a compromise between the "political" and

\footnotetext{
61 CJEU (General Court), 14 December 2018, Case T-801/17, Dermatest Gesellschaft für allergologische Forschung $u$. Vertrieb von Körperpflegemitteln mbH/EUIPO, paras. 73-75; 29 March 2019, Case T-611/ 17, All Star CV/EUIPO, paras. 156-173 (appeal to the CJEU was not allowed to proceed - CJEU, 30 September 2019, Case C-461/19 P), cf. commentary by Martin and Beslier (2019), pp. 534-535; 19 June 2019, Case T-307/17, adidas/EUIPO, paras. 142-159, cf. commentary by Strath and Cameron (2019), pp. 721-722; 28 June 2019, Case T-340/18, Gibson Brands, Inc./EUIPO; 12 July 2019, paras. 55-79; Case T-264/18, Gruppo Armonie SpA/EUIPO, paras. 46-55.

62 The lack of clarity of the picture that comes out of the case law in this regard is stressed, for example, by Kur, in: Kur and Senftleben (2017), p. 204; Bently et al. (2018), p. 1010; Jung (2019), p. 255.

63 Martin and Beslier (2019), p. 535; Jung (2019), p. 255.

64 Dinwoodie (2004), p. 888; Dinwoodie (2017), p. 1700.

65 Recital 3 EUTMR.
} 
"intrinsic" scope of protection. This has been achieved by recognising an EU-wide scope of infringement and relief as a rule, but also appreciating the "intrinsic" territoriality by allowing exceptions to this rule and, thus, opening up the possibility of a territorially confined scope of relief ( $c f$. Sect. 6).

There is, however, a major difference between the assessments made at the level of infringement as compared with the level of registration. Caveats to unitary character at the level of infringement (and enforcement) do not affect the unitary character of the already granted exclusive right to the EUTM. A right that has been found to have been infringed only in a part of the EU in a given dispute still remains unitarily effective in the EU. ${ }^{66}$ Therefore, the dissonance between the "intrinsic" and "political" scope of protection at the level of infringement can be viewed as possible without striking at the heart of the principle of unitary character. At the level of registration, however, the very creation of the unitary right is at stake and in this case there is no room for exceptions. ${ }^{67}$ It is about whether or not a unitary right comes into existence. This might explain why the case law prefers to take the position that the EUTM must be distinctive everywhere in the EU in order to be registered. However, such an approach gives rise to systematic doubts. It appears hardly reconcilable with the principle of unitary character, because it leads to adopting a methodology that assumes treating the internal market in any instance for the purpose of determining acquired distinctiveness of an EUTM as a territory divided into national markets. This is striking, because on other occasions whenever the issue of the relevance of frontiers between Member States was invoked in connection with specific problems arising in the light of the EUTMR, the CJEU has been quite consistent in stressing the need to disregard national borders. As stated by the CJEU with regard to territorial aspects of genuine use ${ }^{68}$ or the territorial reach of reputation of an EUTM "in the Union", 69 an opposing approach would not be reconcilable with the principle of unitary character. Therefore, the country-bycountry method with regard to acquired distinctiveness constitutes a departure from the otherwise border-detached approach of the CJEU. The reasons for this are not sufficiently explained in case law. On the other hand, this departure, even if not clearly substantiated, might imply that the CJEU is motivated by the abovementioned different logic underlying the acquisition of rights as opposed to the maintenance of already existing rights ${ }^{70}$ (or enforcement thereof). Perspectives of approaching these dilemmas are examined in subsequent parts.

\footnotetext{
66 Cf. CJEU, 22 September 2016, Case C-223/15, combit Software/Commit Business Solutions, para. 35.

${ }^{67}$ In a similar vein, Sosnitza (2013), p. 107; an exceptional regulation is contained in Art. 209(2) and (4)(a) EUTMR, which stipulates that applicability of any absolute grounds for refusal occurring merely due to accession of new Member States cannot lead to a refusal or invalidation with regard to marks already registered or applied for at the date of the accession (the protection of such marks had been extended to new Member States).

68 CJEU, 19 December 2012, Case C-149/11, Leno Merken/Hagelkruis Beheer, paras. 41-44.

69 CJEU, 6 October 2009, Case C-301/07, PAGO/Tirolmilch, para. 27.

${ }^{70}$ Cf. Folliard-Monguiral and Rogers (2013), p. 287.
} 


\section{Room for a More Unitary Approach Towards Establishing Acquired Distinctiveness of EUTMs?}

\subsection{Impact of the Principle of the Unitary Character of the EUTM}

The remarks in Sect. 3 allowed the conclusion to be drawn that the division of the internal market into sub-markets determined across national borders should not - as a rule - be necessary for assessing inherent distinctiveness of non-word EUTMs where linguistic considerations do not play a role. On the other hand, descriptiveness or otherwise indistinctiveness of word EUTMs, where territorially, linguistically varying perceptions are crucial, will - as a rule - involve looking at submarkets usually tailored along borders between individual Member States, or delimiting groups of Member States where similar linguistic conditions are present.

A corresponding approach towards establishing acquired distinctiveness of EUTMs would invite a prima facie conclusion that whenever no need arises to refer to territorially varying consumer perceptions with a view to establishing a lack of inherent distinctiveness, there should be no justification for a division of the internal market into sub-markets for the sake of assessing acquired distinctiveness. Instead, it would seem a natural consequence in such instances to consider the EU as one territory undivided by borders between Member States. The case law does not, however, follow this logic. As indicated in Sect. 4, despite the readiness in the case law to establish a lack of inherent distinctiveness of non-word marks in the entire EU without territorial references, the presence of acquired distinctiveness is still required in every Member State, even if theoretically some relaxation on the evidentiary level is simultaneously provided.

There appears to be no justification for applying this border-oriented approach as a general and universal method. First and foremost, it indeed gives rise to doubts from the perspective of the principle of unitary character. One should observe that while the principle of unitary character is clearly anchored in Art. 1(2) EUTMR, the requirement that an EUTM must be distinctive in every EU Member State does not have such a normative grounding. In particular, despite extensive case law considering that a single Member State might constitute a "part" of the EU within the meaning of Art. 7(2) EUTMR, it should be stressed that this provision employs the word "part" not "Member State". It does not, therefore, per se impose an application of a border-oriented criterion. A coincidence between a "part of the EU" and territory of even one Member State or several Member States is possible in cases in which the refusal grounds set out in Art. 7(1)(b)-(d) are caused by varying consumer perceptions connected with linguistic reasons. The situation is different in cases of a lack of inherent distinctiveness of non-word marks with no varying consumer perceptions involved, when the presence of the refusal ground set out in Art. 7(1)(b) EUTMR is not linked with any specific part of the EU. In that case, proving acquired distinctiveness in accordance with Art. 7(3) EUTMR should allow the refusal ground set out in Art. 7(1)(b) EUTMR to be overcome directly, and not in conjunction with Art. 7(2) EUTMR, since there is no individual part of the EU affected by this refusal ground. With this position in mind, there should be no reason to assume that a lack of acquired distinctiveness in, for example, just one or two 
Member States must inevitably result in the EUTM's ineligibility for registration. Instead, this view allows taking a more unitary approach towards the assessment of acquired distinctiveness.

One can conclude at this point that the principle of unitary character should indeed affect the approach towards establishing the acquired distinctiveness of an EUTM in the manner presented above. More specifically, the position argued postulates the need to adhere to this principle for the purpose of assessing acquired distinctiveness by avoiding a fragmentation of the EU territory whenever no varying consumer perceptions have been necessary to establish a lack of inherent distinctiveness of a mark. Caveats to this rule should only be justified in situations involving varying consumer perceptions. These are caused - as a rule (as argued in Sect. 3) - by linguistic reasons concerning word marks.

\subsection{Towards the Positive Content of the Requirement Concerning the Territorial Scope of Acquired Distinctiveness of an EUTM}

The mere negation of the country-by-country assessment of acquired distinctiveness in cases of inherent distinctiveness lacking in the entire EU with no varying consumer perceptions involved, could not, however, of itself offer an answer concerning the positive requirements of assessing the territorial reach of acquired distinctiveness. Pursuing the unitary approach could encourage the argument that no different assessment should be made in this case than in national cases, where it is not necessary to demonstrate acquired distinctiveness throughout the entire territory of a given state. Consequently, the presence of acquired distinctiveness among a substantial proportion of consumers in the EU, taken as a whole, would be sufficient. $^{71}$ It is, however, hard to ignore the great geographical scale of the protection of EUTMs, which renders the aspect of the territorial scope of acquired distinctiveness thereof quite unique and different from the national setting. Therefore, the requirement that a substantial part of the public in the EU taken as a whole must recognise the distinctiveness of an EUTM appears to be too abstract to be applied in practice, if it is detached from guidance concerning the geographical scope of the territory in which the substantial part of the public should be found. This might justify why there has been so much focus in case law, and in the legal doctrine, just on the sole issue of the territorial aspect of acquired distinctiveness of EUTMs.

More tempting could be comparisons drawn between the EUTM system which co-exists with national trade mark protection regimes in Member States, and the US system in which federal registrations co-exist with state trade mark protection regimes. In this regard, it has been suggested that obtaining a federal US registration based on acquired distinctiveness (secondary meaning) does not require demonstrating its presence everywhere in the US territory, and even a presence in a small territory could be sufficient. ${ }^{72}$ There may, however, be doubts as to whether the level of integration of the market in the entire territory of protection is as advanced

\footnotetext{
71 Porangaba (2019), pp. 640, 659-662.

72 Porangaba (2019), pp. 659-660, including fn. 193.
} 
in the EU as in the US, in particular in the areas relevant for issues of trade mark protection. $^{73}$ It is also not without significance that federal registration is the dominant method of protecting trade marks in the US, making state protection far less important. ${ }^{74}$ By contrast, in the EU, despite a reduction in the number of national trade mark applications in most Member States and the increase in EUTM applications, ${ }^{75}$ there is still a considerable role for national regimes of protection. ${ }^{76}$ This might demonstrate that there are industries and markets that are not strongly integrated into the internal market in the EU. ${ }^{77}$

How then could the positive requirements of establishing acquired distinctiveness of EUTMs under the territorial aspect be formulated? Would the presence of acquired distinctiveness in a substantial part of the EU be sufficient? Should this part cover the majority of the territory of the EU? Should there be factors (relevant just for the sole territorial aspect) other than the mere quantitative proportion of the territory of the EU and the population living there? Answering these questions is not an easy task and it calls for a certain framework.

As already raised above, in the case of assessment of acquired distinctiveness there is really no room at the stage of registration to introduce any relaxation of the unitary effect of the EUTM, since it is about the very creation of the unitary exclusive right, whereas at the stage of infringement there is some leeway to introduce exceptions to the unitary effect of an already existing unitary right ( $c f$. Sect. 4). In view of this "all or nothing" effect of the EUTM registration, the question about the geographical reach of acquired distinctiveness is one about the extent to which the EUTM system is (or should be) oriented to moving ahead of the actual market understanding of an EUTM as a trade mark, for the sake of pursuing the concept of treating the EU as one territory of protection, or to what extent priority should rather be given to the actual market understanding of a sign as a trade mark. ${ }^{78}$ The tendency in case law to eliminate, or at least narrow, the dissonance between the formal territorial scope of unitary protection and the actual territorial scope of acquired distinctiveness might be read as underpinned by fears that the integration of the internal market is insufficient to look "unitarily" at the EU. ${ }^{79}$ Although the country-by-country approach is vulnerable to criticism from the perspective of the principle of unitary character, these concerns, apparently noticed by the CJEU, should not be disregarded when attempting to formulate the desirable

\footnotetext{
73 Cf. Dinwoodie (2017), p. 1726, indicating, in connection with dilemmas concerning the concept of the average European consumer, that there is a congruency between the political territory of protection of federal marks and the commercial and social reality in the US, whereas the EU unitary market is a fiction that does not correspond to reality.

74 Bereskin (2011), p. 99; Dinwoodie (2017), pp. 1678, 1682.

75 Dinwoodie (2017), pp. 1683-1684, with some exceptions, notably in the UK, Germany and France; $c f$. also the relevant statistics up to the year 2015, ibid., pp. 1734-1743.

76 Dinwoodie (2017), pp. 1681-1682.

77 Study (2011), pp. 63-64 (para. 1.77).

78 Dinwoodie (2017), p. 1726, stresses in a general manner the need for a normative clarification of goals pursued by the EUTM system in the context of concepts of "political" and "intrinsic" territoriality.

79 As observed by Tritton (2012), p. 236, there is a degree of realpolitik in the country-by-country approach in case law.
} 
content of the requirement concerning the territorial presence of acquired distinctiveness, while simultaneously trying to take a more unitary approach.

An obvious inconvenience, linked with the current country-by-country approach, is that the requirement of evidencing acquired distinctiveness in every Member State puts a considerable burden on the applicant. As has been raised, this might render obtaining a registration with acquired distinctiveness virtually impossible. ${ }^{80}$ One could argue, however, that even when rejecting the country-by-country approach the latter argument should still be balanced against the need to take account of other interests involved, notably the interests of consumers and other traders. There are several aspects that should be taken into consideration in this regard.

First, trade marks lacking inherent distinctiveness in the EU with no specific territorial link might often concern non-conventional marks. This is a fragile issue from the perspective of consumer perceptions. While the case law stresses that the test for distinctiveness of such marks as shapes or colour marks should not be higher than with regard to other types of marks, it simultaneously indicates that since the public is not normally accustomed to treating such forms as indicators of the commercial origin of goods, it may in practice be more difficult to establish distinctiveness thereof, ${ }^{81}$ and such forms should significantly depart from the norm or customs of the relevant sector in order to be distinctive. ${ }^{82}$ Therefore, when examining the issue of the geographical aspect of acquired distinctiveness of EUTMs, one should not only look at the fact that burdensome requirements might make obtaining protection difficult for applicants, but one should also look at the interest of consumers resting on the fact that, given the territorial greatness of the EU, there is a sufficient geographical scale of consumer understanding of a certain sign as performing the function of a trade mark.

Second, one could postulate a more balanced assessment of acquired distinctiveness that would, next to consumer perceptions, also take into the equation competition concerns and the need to leave certain marks in the public domain for other traders regardless of their factual distinctiveness, if functional features of such marks are not eminent enough to reject them on the basis of the permanent exclusions set out in Art. 7(1)(e) EUTMR. The "need to keep free" perspective appears to be missing in the CJEU case law, given the focus on consumer perceptions in cases of acquired distinctiveness. ${ }^{83}$ This raises concerns, and suggestions have even been made to exclude registrations of certain signs, notably non-conventional signs, regardless of their acquired distinctiveness as otherwise the public domain might be endangered. ${ }^{84}$ Fears connected with the preservation of the

\footnotetext{
${ }^{80}$ Cf. Tritton (2012), p. 235; Grabrucker (2019), p. 153, para. 6.

81 In relation to shapes: CJEU, 12 February 2004, Case C-218/01, Henkel/Deutsches Patent- und Markenamt, para. 52; 8 April 2003, Joined Cases C-53/01, C-54/01 and C-55/01, Linde/Winward Industries Inc./Rado Uhren AG, para. 48. In relation to colour marks: CJEU, 6 May 2003, Case C-104/01, Libertel Groep/Benelux-Merkenbureau, para. 65.

82 CJEU, 12 February 2004, Case C-218/01, Henkel/Deutsches Patent- und Markenamt, paras. 49 and 52.

83 Davis (2002), pp. 359-365; Sosnitza (2013), p. 106; Kur, in: Kur and Senftleben (2017), pp. 209-210.

84 Anemaet (2016), p. 303. For dilemmas in this area from the US perspective, $c f$. Lunney (2018), p. 217.
} 
public domain could be a further factor that would call for a measured approach when examining territorial aspects of acquired distinctiveness of an EUTM. This position would correspond to the proposal for an integrated approach that would allow taking into account and balancing all interests involved with regard to the application of all refusal grounds set out in Art. 7(1)(b), (c) and (d) without tailoring each of these refusal grounds to one group of interests. ${ }^{85}$

Third, there is a clearly noticeable tendency in the legal scholarship towards searching for a mitigating tool against the potentially overly excessive effects of unitary protection of EUTMs registered with acquired distinctiveness at the infringement level ( $c f$. Sect. 6). While this, of itself, is a justified direction, also advocated in this paper, there are, however, arguably drawbacks to such a solution, mostly from the perspective of the interests of other traders (competitors). Therefore, a more viable model appears to be one in which a proper balance of all interests involved is provided by a combination of tools, namely, first, a proper control at the registration level with, second, a further possibility of mitigating some potential negative consequences of the registration at the infringement level.

With this framework in mind, the question recurs about the positive content of the requirement concerning the geographical scope of acquired distinctiveness of an EUTM at the level of assessing its eligibility for registration that would simultaneously depart from the country-by-country approach currently adopted in case law.

The unitary approach could, at first glance, consist of applying the substantialpart criterion as employed in early case law ( $c f$. Sect. 4) and advocated in literature. ${ }^{86}$ However, the requirement, so framed, opens more questions than it provides answers, particularly in the light of the content that was given to the notion of the "substantial part" in the CJEU's PAGO decision. In this judgment, the CJEU ruled that for an EUTM to benefit from extended protection enjoyed by marks with a reputation "in the Union", based on Art. 9(2)(c) EUTMR, an EUTM must be known by a significant part of the public concerned by the goods or services covered by the mark in question in an important (significant) part of the territory of the Union. Simultaneously the CJEU acknowledged that the territory of Austria was a significant part of the Union. ${ }^{87}$ It is worth noting that criticism exercised in case law after $P A G O$ over the application of the "substantial part" criterion with regard to cases of acquired distinctiveness was expressed based on the assumption that a "substantial part" in the latter cases would be given the same meaning as in $P A G O{ }^{88}$ This criticism finds reasonable justification. Since, in the light of PAGO, a territory of one Member State could constitute a "substantial part" of the EU, establishing a "substantial part" in this sense would not automatically allow $a$ contrario describing the remainder of the EU as a "non-substantial part". In other

\footnotetext{
85 Kur, in: Kur and Senftleben (2017), p. 115.

86 Porangaba (2019), p. 662.

87 CJEU, 6 October 2009, Case C-301/07, PAGO/Tirolmilch, para. 30.

88 CJEU (General Court), 29 September 2010, Case T-378/07, CNH Global/OHIM, para. 47; 6 July 2011, Case T-318/09, Audi/OHIM, paras. 55-57; 21 April 2015, Case T-359/12, Louis Vuitton Malletier/OHIM, para. 119.
} 
words, the PAGO formula is not based on a "substantial" versus "non-substantial" dichotomy, but there could rather be numerous "substantial parts" of the EU. This poses problems in the area of acquired distinctiveness if the existence of distinctiveness in a "substantial part" of the EU (which could, in a given situation, consist of a single Member State) were sufficient to overcome the registration bar. This would mean that an EUTM is eligible for registration, although it could be deprived of distinctiveness in a considerable, "substantial" rest of the EU. This scenario could hardly be accepted, ${ }^{89}$ especially in the light of the framework outlined above, aimed at balancing the various interests involved. It, therefore, appears that the territorial requirement would have to be much greater than the "substantial part" criterion as understood in PAGO.

This implies searching for a more extensive quantitative scope of the territory in which acquired distinctiveness should be present. The mere criterion of, for example, a "large" part or "majority of the territory" of the EU would not necessarily be sufficient. For instance, if a shape mark was substantially used in northern and western Europe, but would not be used in the south and east, granting unitary protection to such a mark could be problematic with regard to the territories where the mark is perceived as merely decorative. ${ }^{90}$ It appears that any criterion which focuses on a "part" (used in the singular) of the Union, be it a "substantial part", "large part" or even a "majority" of the territory, resonates too distinctly with a certain potential for excluding the remaining part of the EU. It also encourages opposition towards a more unitary approach such as the one set out by the General Court in Mondelez, stating that the lack of perception of a particular sign as an indication of commercial origin of goods in a certain part of the EU cannot be offset by a high degree of such perception in another part of the Union. ${ }^{91}$

This directs attention towards an approach that is not just oriented to the size of the geographical area where acquired distinctiveness should be present, but also takes account of the geographical spread of acquired distinctiveness. One can, therefore, argue that not only a respective quantitative criterion pertaining to a considerable proportion of the territory of the EU should be applied, but also this large proportion, conceivably covering in quantitative terms the majority of the EU territory, should be combined of parts located at a proper geographical spread. It is argued that territories of the EU where acquired distinctiveness has not been established should rather constitute "blank" areas sporadically scattered across the EU. Such "blank" areas could correspond to territories of a specific Member State or Member States. These "blank" areas should not, however, together constitute a concentrated larger part of the EU. It cannot be ruled out that with the deployment of this approach the evidence of acquired distinctiveness of the "KIT KAT" shape mark in the Mondelez case, covering territories of numerous Member States at a wide geographical spread representing $90 \%$ of the EU population, on the date of the application of the mark in question, and indicating that almost half of the population in that territory identified this mark as an indicator of the commercial origin of the

\footnotetext{
89 Sosnitza (2013), p. 107.

90 Kur, in: Kur and Senftleben (2017), pp. 205-206.

91 CJEU (General Court), 15 December 2016, Case T-112/13, Mondelez/EUIPO, para. 142.
} 
product, could be considered as sufficient for establishing an acquired distinctiveness of this mark in the EU taken as a whole. ${ }^{92}$ On the other hand, it appears that circumstances such as those in Basic Net, when acquired distinctiveness could be established only in the territories of four large Member States, representing approximately $40 \%$ of the population of the EU, could not be considered as sufficient to establish acquired distinctiveness in the light of the proposed approach.

The posited more unitary approach could probably again invite criticism. First, it could be raised that the proposal might disadvantage smaller and less populous Member States that are more likely to be considered as sporadic "blank" areas. The proposed approach should not, however, be understood in the sense that providing evidence of acquired distinctiveness only in larger and populous Member States, such as France, Germany, Italy, Poland or Spain, would be sufficient to overcome a lack of inherent distinctiveness in the EU. No "default" disadvantage for smaller Member States is intended in this proposal. Admittedly, however, the smaller size and population of a given Member State or even several Member States, which are not situated in proximity to each other, might contribute to considering them under circumstances of a given case as isolated "blank" areas in comparison with the vast and proportionate territorial spread of an established presence of acquired distinctiveness in the EU. Consequently, a lack of acquired distinctiveness in such areas would not disrupt the registrability of an EUTM when pursuing a more unitary approach, since the latter focuses on the internal market as a unitary market area. Next, the risks of overprotection in territories referred to above as "blank" areas could still be mitigated with tools available at the stage of infringement and enforcement of an EUTM, which is an issue addressed in Sect. 6.

On the other hand, the emphasis put in the above proposal on the vast and proportionate geographical spread of established acquired distinctiveness with only sporadic "blank" areas permitted could raise criticism from proponents of a greater liberalisation of assessments. They could still point out a considerable evidentiary burden put on the applicant in this proposal. The argued position is, however, based on the necessity to take other interests into the equation, rather than just the interests of applicants. It should also be remembered that when the requirement of acquired distinctiveness in the EU could not be satisfied, an applicant might always turn to national applications in these Member States in the territories for which acquired distinctiveness could be established. Moreover, the applicant, while being backed by the protection already secured by national trade marks, is free to undertake further efforts towards "educating" a sufficient proportion of consumers in the EU on a proper geographical scale to treat a given sign as distinctive. This might, thus, increase the chances of a successful registration based on acquired distinctiveness at the EU level in the future.

\footnotetext{
$92 C f$. a successful registration of the shape of a tyre based on acquired distinctiveness in comparable conditions - decision of the Second Board of Appeal, 10 October 2001, Case R 126/2001-2 Pirelli Pneumatici, paras. 18, 22.
} 


\subsection{Perspectives in the Light of Current Case Law}

A more unitary approach towards defining acquired distinctiveness as a fact that needs to be proved in cases of an EU-wide absence of inherent distinctiveness, however, remains a postulate, since case law prefers to define this fact as relating to acquired distinctiveness existing throughout all Member States. In turn, the CJEU in Lindt and next in Mondelez offered a different solution that could - at least theoretically - mitigate the effects of the strict country-bycountry approach by stressing that it was not necessary to submit evidence for each individual Member State in every instance, but the evidence could be "relevant with regard to several Member States, or even to the whole of the European Union". ${ }^{93}$ This might encourage searching for some potential for a unitary approach under the current case law, at least with regard to evidentiary requirements.

As indicated in Sect. 4, in Mondelez the Court of Justice gave two further examples of how the lack of a requirement of separate evidence for every Member State could operate. The scope of the first example, concerning common evidence covering a group of Member States treated by the EUTM applicant in its marketing strategy as just one national market, is, however, obscure. It is not clear whether this criterion should be oriented to the marketing strategy of the individual applicant or should rather take into account a general perspective of settled strategies in a given branch. ${ }^{94}$ Regardless of these uncertainties, the potential of this example for achieving a more unitary approach is also dubious. It would greatly increase if the content of the CJEU's statement carried with it explicit permission for extrapolation of conclusions based on available evidence concerning some of the Member States in a respective sub-market to other Member States in the same sub-market. As indicated above, AG Wathelet's opinion in Mondelez allowed such an extrapolation based on the criterion of comparability of national markets. This approach has also been considered as acceptable in the EUIPO's Guidelines. ${ }^{95}$ It was not, however, expressly reiterated by the CJEU in the Mondelez judgment. This might leave the door open as to whether the CJEU would indeed allow such an extrapolation, or whether it merely intended to allow evidence that collectively pertained to the territory of a given sub-market comprised of several Member States, leaving, however, no doubt that such evidence must cover the entire territory of this respective sub-market.

\footnotetext{
93 CJEU, 25 July 2018, Joined Cases C-84/17 P, C-85/17 P and C-95/17 P, Nestlé/Mondelez/EUIPO, para. 80 .

94 Rightly noticed by Porangaba (2019), p. 647.

95 EUIPO Trade mark guidelines, Edition Legislative Reform II of 2017 (in force until 31 January 2020), Part B, Section 4, Chapter 14, point 6.3, first, on condition of homogeneity of a respective trans-border market and, second, provided there was at least some evidence of use for the area to which the conclusions from evidence were extrapolated, at: https:/guidelines.euipo.europa.eu/1803422/1704202/ trade-mark-guidelines/6-3-extrapolation [Accessed 16 March 2020]. Current Guidelines (in force as of 1 February 2020) differentiate-in the same point 6.3-between regionalisation, being division of the EU market into regional segments as per the Mondelez judgment, and extrapolation of evidence, at: https:// guidelines.euipo.europa.eu/1803422/1789190/trade-mark-guidelines/6-3-acquired-distinctivenessthroughout-the-eu [Accessed 16 March 2020].
} 
The second example indicated by the Court of Justice concerns a situation where "due to a geographic, cultural or linguistic proximity between two Member States, the relevant public of the first has a sufficient knowledge of the products and services that are present on the national market of the second". ${ }^{96}$ If this example were to be given any real content as an exemption from the necessity of providing evidence for every individual Member State, it should be construed as allowing some room for extrapolation of conclusions coming from evidence directly concerning the territory of a given Member State to the territory of another Member State for which no evidence has been provided at all, or the type of evidence provided does not allow making decisive conclusions regarding the presence of acquired distinctiveness or a lack thereof. While linguistic or cultural proximity does indeed assume varying consumer perceptions in specific regions of the EU, the factor of geographical proximity does not necessarily do so. Therefore, it could play a role in cases of acquired distinctiveness of non-word marks, when no varying perceptions are relevant. One should note, however, that the CJEU has accepted relaxations merely on the evidentiary level without abandoning the country-bycountry approach on the level of acquired distinctiveness as a fact to be proved. Consequently, if a third party contesting the registration of an EUTM in invalidation proceedings presents proof that a certain sign is not recognised as distinctive in a given Member State, it should open up the possibility of contesting the registration of an EUTM with a justification that the employment of evidentiary relaxation set out in Mondelez has led to incorrect assessments at the stage of registration. This appears to be the consequence of the line drawn in Mondelez between the issue of acquired distinctiveness throughout the EU as the fact that needs to be proved and evidence necessary to prove this fact. By contrast, a unitary approach posited in this paper would allow maintaining the registration despite a lack of acquired distinctiveness in a given Member State and despite Art. 7(2) EUTMR. In such a case, the respective framework for mitigating overly excessive effects of unitary registrations could be provided at the level of infringement ( $c f$. Sect. 6).

Finally, varying consumer perceptions do play a role with regard to the assessment of descriptiveness or otherwise indistinctiveness of word marks that are caused by linguistic reasons. As indicated in Sect. 3, in order to establish ineligibility of such signs for registration there is a need to take into account unique language conditions existing in sub-markets in which a given language is used or in which a foreign word or expression is understood. Consequently, the same approach should be applied to establishing the acquired distinctiveness of such marks, which means that the territorial reach of acquired distinctiveness should be established individually in every respective linguistic sub-market where a mark has been considered descriptive or otherwise indistinctive. Such sub-markets might, depending on the circumstances of the case, coincide with the territory of a single Member State or a group of Member States. This approach certainly entails a weakening of the unitary character, which has to concede to the fragmentation of the internal market due to varying consumer perceptions. In Mondelez, the CJEU in its

\footnotetext{
${ }^{96}$ CJEU, 25 July 2018, Joined Cases C-84/17 P, C-85/17 P and C-95/17 P, Nestlé/Mondelez/EUIPO, para. 82 .
} 
second scenario of evidentiary relaxations expressly referred, however, to linguistic proximity between two Member States as a factor that might justify formulating conclusions with regard to one Member State based on evidence from another. Bearing this in mind, there could be some room for the territorial extrapolation of the relevance of evidence of acquired distinctiveness covering one Member State to the territory of another Member State, both of them belonging to the same linguistic sub-market that is made up of several Member States (e.g. French-speaking countries).

\section{Mitigating Mechanisms at the Infringement and Enforcement Level}

This final section of the paper examines the mechanisms for a potential mitigation of overly excessive consequences of the unitary effect of EUTMs registered with acquired distinctiveness that could be applied at the level of infringement. As will be further demonstrated, the legal framework in the light of the EUTMR and the relevant case law does provide viable opportunities in that regard. There are, however, certain drawbacks that cannot be disregarded in the overall perspective.

As a starting point, one should note that the Court of Justice in its judgment in the DHL case $^{97}$ and in subsequent case law ${ }^{98}$ has paved the way to, on the one hand, confirming that the scope of injunctions against infringement of an EUTM is "as a rule" EU-wide, while, on the other hand, simultaneously allowing exceptions to this rule. These exceptions have been allowed, first, when the claimant has restricted the territorial scope of its action and, second, when the defendant is able to prove that the use of its sign does not affect or is not liable to affect the functions of the earlier EUTM; for example, due to linguistic differences affecting a part of the EU. ${ }^{99}$ In framing the second $D H L$ exception, the CJEU referred to the so-called "functions theory" established in its own case law, according to which the exercise of the exclusive right to a trade mark must be restricted to cases in which a third party's use of the sign affects or is liable to affect the functions of the trade mark. ${ }^{100}$ Based on this case law, the CJEU opened up the possibility of denying an infringement and enforcement of an EUTM in a part of the EU in which an interference with the functions of a given EUTM or a threat thereof is not present. ${ }^{101}$ This approach is, indeed, a certain weakening of the effects of unitary character. It is, however, underpinned by the endeavour to find a compromise between the wide "political"

\footnotetext{
97 CJEU, 12 April 2011, Case C-235/09, DHL/Chronopost, paras. 44-48.

98 CJEU, 22 September 2016, Case C-223/15, combit Software/Commit Business Solutions; 20 July 2017, para. 36; Case C-93/16, Ornua/Tindale \& Stanton, paras. 29-33.

99 CJEU, 12 April 2011, Case C-235/09, DHL/Chronopost, para. 48.

${ }^{100}$ Cf., in particular, CJEU, 12 November 2002, Arsenal Football/Matthew Reed, paras. 51 and 54; 18 June 2009, Case C-487/07, L'Oréal et al., paras. 58-60.

101 CJEU, 12 April 2011, Case C-235/09, DHL/Chronopost, paras. 46-48; 22 September 2016, Case C-223/15, combit Software/Commit Business Solutions, paras. 27-36; and 20 July 2017, Case C-93/16, Ornua/Tindale \& Stanton, paras. 29-33.
} 
formal scope of protection and the scope of the actual "intrinsic" territoriality of protection. $^{102}$

In the context of problems connected with acquired distinctiveness, the second exception could be applied to refuse protection at the level of infringement in territories where, due to descriptiveness or otherwise indistinctiveness of a given EUTM, no interference with its functions could be established. ${ }^{103}$ This has already been demonstrated by the circumstances of such CJEU cases as $D H L$ or combit ${ }^{104}$ that were linked with territorially varying consumer perceptions of word marks caused by linguistic reasons. It appears, further, that a similar mechanism could be used to deny an infringement action with regard to a certain territory of the EU in which a non-word EUTM would lack distinctiveness despite having been registered with acquired distinctiveness.

A further possible mitigating mechanism in the above-described situation could be offered by the limitation of the right to an EUTM concerning use of nondistinctive or descriptive signs or indications (Art. 14(1)(b) EUTMR), as long as it complies with the honest practices' requirement set out in Art. 14(2) EUTMR. ${ }^{105}$ The limitation for non-distinctive use was added in the reformed EU trade mark law, while the limitation concerning descriptive use was already in place prior to the reform (Art. 12(1)(b) Reg. No. 207/2009 ${ }^{106}$ ). The role of the added nondistinctiveness limitation is not entirely clear. ${ }^{107}$ It remains to be seen how it will operate. In particular, what its relation would be to the aforementioned positive infringement criteria, as well as to the absolute ground for refusal set out in Art. 7(1)(b) EUTMR 2017. The very fact that this limitation is present in the EUTMR, however, encourages exploring its potential as a mitigating tool, enabling a territorially confined denial of the infringement claim caused by non-distinctiveness or descriptiveness of an earlier EUTM in a given territory within the EU. It would, therefore, operate in a similar way to the criterion of geographically limited interference with an EUTM's functions as justifying a territorially confined infringement and enforcement of the EUTM as per the second DHL exception to EU-wide injunctions. ${ }^{108}$

The above-described tools for mitigating the effects of unitary protection at the level of infringement can already be employed under the current framework provided by the EUTMR and its interpretation adopted in case law. The role of such instruments would, however, gain in importance if one could apply the unitary approach towards assessing the registrability of an EUTM at the stage of registration

\footnotetext{
$\overline{102}$ Dinwoodie (2017), pp. 1700-1701.

103 Porangaba (2019), pp. 662-669.

104 CJEU, 12 April 2011, Case C-235/09, DHL/Chronopost; 22 September 2016, Case C-223/15, combit Software/Commit Business Solutions.

105 Study (2011), p. 147 (para. 3.75); Kur, in: Kur and Senftleben (2017), p. 206; Kur and Senftleben (2017), pp. 416-417; Kur (2018), p. 102.

106 Cf. fn. 1.

107 Kur and Senftleben (2017), pp. 415-417; Bently et al. (2018), p. 1139.

$108 C f$. von Mühlendahl (2008), p. 68, accepting a territorially confined scope of the limitation concerning descriptive signs under Art. 12(1)(b) Reg. No. 207/2009.
} 
posited in this paper. This would be due to the fact that while - as per the approach argued in Sect. 5.2 - EUTMs could be found in given circumstances as incontestable in invalidation proceedings, despite not being distinctive in some Member States, they could, nevertheless, potentially be incapable of being infringed and enforced in those Member States due to a lack of distinctiveness. For the time being, under the current country-by-country approach adopted in case law, with regard to establishing acquired distinctiveness in the entire EU (as a fact that needs to be proved), the situation differs insofar as a wrongly assessed - at the stage of registration - presence of acquired distinctiveness of an EUTM in a given Member State based on prima facie evidence is concerned. In such instances, the above mitigating tools could, of course, be applied and consequently the presence of infringement in that Member State be denied. Simultaneously, however, a lack of acquired distinctiveness even in one Member State could justify an invalidation of the EUTM in question as lacking distinctiveness in a part of the EU within the meaning of Art. 7(2) EUTMR ( $c f$. a wider explanation in Sect. 4).

One must not, however, disregard the drawbacks of the deployment of the functions theory or limitations as tools for mitigating overly excessive effects of unitary protection of EUTMs registered with acquired distinctiveness. One could raise, in the first instance, concerns about the position of other traders. When formulating the second exception set out in $D H L$, the CJEU indicated that it was the defendant who needed to present proof of a lack of interference with the functions of an EUTM in a part of the EU. ${ }^{109}$ This remains valid case law, even if the scope of this shift of the burden of proof might not be entirely clear. ${ }^{10}$ That the burden of proof rests with the defendant is even more obvious if the defendant would like to invoke the limitation concerning the use of indistinctive signs set out in Art. 14(1)(b) EUTMR. Both situations might involve costs on the part of the defendant connected with collecting respective evidence; for example, in the form of surveys demonstrating a lack of distinctiveness of a given mark in a given territory. In that regard, it is worth noting that so far the CJEU has stressed on several occasions, with regard to the limitation covering use of descriptive signs, that a potential reliance on this limitation by the defendant in infringement proceedings did not justify a more liberal approach towards the application of the refusal ground for descriptive signs under Art. 7(1)(c) EUTMR at the stage of assessing eligibility for

\footnotetext{
109 CJEU, 12 April 2011, Case C-235/09, DHL/Chronopost, para. 48; 22 September 2016, Case C-223/ 15, combit Software/Commit Business Solutions, para. 32 (put slightly less forcefully than in DHL, by indicating that the evidence of a lack of interference with a trade mark's functions must be submitted by the defendant "as a rule"); in a different vein, Porangaba (2019), p. 669, raises that the claimant would have to demonstrate distinctiveness of its mark in the part of the EU for which no proof had been required in the registration proceedings.

110 In the judgment of the High Court of England and Wales of 11 February 2015, Enterprise Holdings Inc v. Europcar Group UK Ltd, [2015] EWHC 300 (Ch), paras. 9-10, the relevance of the shift of the burden of proof rule was challenged with regard to other types of infringement than double identity (Art. 9(1)(a) EUTMR). Cf. Knaak and Żelechowski (2016), pp. 267-268; Dinwoodie (2017), pp. 1709-1717. Cf. also the critical opinion of AG Szpunar towards the Enterprise judgment in the opinion of 25 May 2016, Case C-223/15, combit Software GmbH v. Commit Business Solutions Ltd, paras. 39-40. For doubts, however, concerning the burden of proof as per DHL prior to Enterprise, $c f$. Żelechowski (2013), pp. 294-295.
} 
registration. ${ }^{111}$ This might be read as a signal that, despite the availability of the limitation set out in Art. 14(1)(b) EUTMR (currently also extending to the use of non-distinctive signs), the "gatekeeping" role of the respective refusal grounds should not be liberalised. Generally, the situation of other traders is more difficult where they are faced with an already existing exclusive monopoly over an EUTM and the potential possibility of being forced to argue in their defence a lack of an infringement of this right in a given part of the EU in court proceedings, as compared to a situation where there is no exclusive right to an EUTM at all that could be infringed, because the sign in question was considered as ineligible for registration due to a lack of inherent distinctiveness and insufficient territorial reach of acquired distinctiveness. The former situation might have a deterrent effect on the use of non-distinctive or descriptive signs by other, especially economically weaker, traders, who might prefer to avoid engaging in costly infringement proceedings with an uncertain outcome. ${ }^{112}$ For the above reasons, as already signalled in Sect. 5.2, applying infringement criteria and limitations should not be viewed as a major tool for preventing overly excessive effects of registrations of EUTMs with acquired distinctiveness. These instruments should instead supplement a properly measured assessment of the territorial scope of acquired distinctiveness already made at the stage of registration.

\section{Concluding Remarks}

It has been argued in this paper that the unitary character of the EUTM should, to the extent possible, affect the assessment of acquired distinctiveness of EUTMs under the territorial aspect. More specifically, whenever no territorially varying consumer perceptions are involved in establishing a lack of inherent distinctiveness of an EUTM in the EU, the territory of the EU should be treated for the sake of establishing acquired distinctiveness of such marks as a monolith undivided by borders between the Member States. This is normally the case when assessing the distinctiveness of non-word marks where linguistic differences do not play a role. Concessions from this unitary approach are necessary whenever territorially varying perceptions are involved. This normally concerns descriptiveness or otherwise nondistinctiveness of word marks due to linguistic differences, usually tailored across borders between Member States. In such circumstances, the presence of acquired distinctiveness should be established in each respective linguistic sub-market.

The posited unitary approach concerning non-word marks should, however, be a measured one and it should properly take into account the quest for a balance within the great geographical territory of the EU of interests of EUTM owners, other

\footnotetext{
${ }^{111}$ CJEU, 6 May 2003, Case C-104/01, Libertel Groep/Benelux-Merkenbureau, paras. 58-59; 21 October 2004, Case C-64/02 P, Erpo Möbelwerk/OHIM, para. 45; 10 March 2011, Case C-51/10 P, Agencja Wydawnicza Technopol/OHIM, paras. 59-62, departing in this way from the position implied earlier on in the Baby Dry case (CJEU, 20 September 2001, Case C-383/99 P, Procter \& Gamble/OHIM, paras. 35-37, put forward even more forcefully in the opinion of AG Jacobs of 5 April 2001, para. 48).

112 Anemaet (2016), p. 331; Kur (2018), pp. 90-91, speaking of a leveraging power of EUTM registration in such cases.
} 
traders and consumers. This should not only justify requiring acquired distinctiveness to be present in a majority of the EU territory, but also to be located at a proper geographical spread (without, however, following the country-by-country method). This approach should lead to providing a proper level of control executed "at the entry", that is, at the stage of assessing the registrability of the EUTM, which can, further, be supplemented by tools available at the level of infringement.

Such a unitary approach remains a postulate, in view of the strict country-bycountry methodology preferred in case law, with only some evidentiary relaxation permitted. At this point, however, this relaxation has an uncertain potential.

Open Access This article is licensed under a Creative Commons Attribution 4.0 International License, which permits use, sharing, adaptation, distribution and reproduction in any medium or format, as long as you give appropriate credit to the original author(s) and the source, provide a link to the Creative Commons licence, and indicate if changes were made. The images or other third party material in this article are included in the article's Creative Commons licence, unless indicated otherwise in a credit line to the material. If material is not included in the article's Creative Commons licence and your intended use is not permitted by statutory regulation or exceeds the permitted use, you will need to obtain permission directly from the copyright holder. To view a copy of this licence, visit http:// creativecommons.org/licenses/by/4.0/.

\section{References}

Anemaet L (2016) The public domain is under pressure - why we should not rely on empirical data when assessing trade mark distinctiveness. IIC 47:303-335

Bently L, Sherman B, Gangjee D, Johnson P (2018) Intellectual property law, 5th edn. Oxford University Press, Oxford

Bereskin DR (2011) Territorial effects of trade mark registrations: A North American perspective. In: In varietate concordia? National and European trademarks living apart together. Office Benelux de la Propriété Intellectuelle (OBPI), The Hague

Davis J (2002) European trade mark law and the enclosure of the commons. IPQ 4:342-367

Davis J (2005) Locating the average consumer: his judicial origins, intellectual influences and current role in European trade mark law. IPQ 2:183-203

Davis J (2015) Revisiting the average consumer: an uncertain presence in European trade mark law. IPQ $1: 15-30$

Dinwoodie GB (2004) Trademarks and territory: detaching trademark law from the nation-state. Houston Law Review 41(3):885-973

Dinwoodie GB (2017) Territorial overlaps in trademark law: the evolving European model. Notre Dame Law Review 92(4):1669-1773

Dinwoodie GB, Gangjee DS (2018) The image of the consumer in EU trade mark law. In: Leczykiewicz D, Weatherill S (eds) The images of the consumer in EU law: legislation, free movement and competition law. Hart Publishing, Oxford, pp 339-379

Folliard-Monguiral A, Rogers D (2013) Community trade mark round-up 2012. JIPL\&P 8(4):277-296

Grabrucker M (rep.) (2019) Circle of European Trade Mark Judges (CET-J). Conclusions of the meeting in Vienna, 27-29 September 2018. GRUR, pp 152-154

Jung I (2019) Der territoriale Nachweis der Verkehrsdurchsetzung bei Unionsmarken. Fallstricke und Anforderungen nach der neueren europäischen Rechtsprechung. IP - Rechtsberater 11:252-255

Knaak R (2001) Grundzüge des Gemeinschaftsmarkenrechts und Unterschiede zum nationalen Markenrecht. GRUR Int 8-9:665-673

Knaak R, Żelechowski Ł (2016) Territorial scope of relief. In: Vivant M (ed) European case law on infringements of intellectual property rights. Bruylant, Brussels, pp 257-274

Kur A (2012) Case C-235/09, DHL Express v. Chronopost, Judgment of the Court of Justice (Grand Chamber) of 12 April 2011. CML Rev 49:753-766

Kur A (2018) Yellow dictionaries, red banking services, some candies and a sitting bunny: protection of color and shape marks from a German and European perspective. In: Calboli I, Senftleben M (eds) 
The protection of non-traditional trademarks. Critical perspectives. Oxford University Press, Oxford, pp 89-106

Kur A, Senftleben MRF (2017) European trade mark law. A commentary. Oxford University Press, Oxford

Lunney GS (2018) Non-traditional trademarks. The error costs of making an exception the rule. In: Calboli I, Senftleben M (eds) The protection of non-traditional trademarks. Critical perspectives. Oxford University Press, Oxford, pp 217-234

Martin S, Beslier S (2019) The General Court confirms the cancellation of the Converse All Star shoe sole as an EU trade mark and indicates that acquired distinctiveness does not require proof by separate evidence for each individual member state. EIPR 41(8):531-535

Porangaba LH (2019) Acquired distinctiveness in the European Union: when non-traditional marks meet a (fragmented) single market. The Trademark Reporter 109(3):619-670

Sosnitza O (2013) Erwerb und Erhalt von Gemeinschaftsmarken. GRUR 2:105-112

Strath J, Cameron K (2019) Go figure! GC strikes out three-stripes: Adidas v EUIPO (T-307/17). EIPR 41(11):719-722

Study on the overall functioning of the European trade mark system. Presented by Max Planck Institute for Intellectual Property and Competition Law, Munich (2011), 15 February 2011. https:// publications.europa.eu/en/publication-detail/-/publication/5f878564-9b8d-4624-ba6872531215967e. Accessed 16 Mar 2020

Tritton G (2012) Distinctiveness and acquired distinctiveness: the approach and territorial aspects. ERA Forum 13:227-239

von Kapff P (2017) EU Trade Mark Regulation, art. 7. In: Gielen C, von Bomhard V (eds) Concise European trademark and design law, 2nd edn. Kluwer Law International, Alphen aan den Rijn, pp 20-84

von Mühlendahl A (2008) Community trade mark riddles: territoriality and unitary character. EIPR 30(2):66-70

Żelechowski $Ł$ (2013) Infringement of a Community trade mark: between EU-wide and non-EU-wide scope of prohibitive injunctions. EIPR 35(5):287-295

Publisher's Note Springer Nature remains neutral with regard to jurisdictional claims in published maps and institutional affiliations. 